\title{
Correlation between Elementary School Students' Mathematics Self-Efficacy and Motivation
}

\author{
Eva Astuti Mulyani ${ }^{1 *}$, Annisa Kasdiyanti ${ }^{1}$, Siti Quratul Ain ${ }^{2}$, Jesi Alexander Alim ${ }^{1}$, \\ Intan Kartika Sari ${ }^{1}$, Mahmud Alpusari ${ }^{1}$ \\ ${ }^{1}$ Prodi PGSD FKIP Universitas Riau Pekanbaru, Indonesia \\ ${ }^{2}$ Prodi PGSD FKIP Universitas Islam Riau Pekanbaru, Indonesia \\ *eva.astuti@lecturer.unri.ac.id
}

Received: January $27^{\text {th }}, 2020$

Revised: February $14^{\text {th }}, 2020$

Accepted: February $19^{\text {th }}, 2020$

\begin{abstract}
This research aims to determine the positive and significant correlation between mathematics selfefficacy and motivation of elementary school students. This type of research is quantitative using the correlation method. The population of this research was all fifth grade students of Elementary School in Cluster I of Marpoyan Damai District in Pekanbaru, which totaled 705 students. The research sample consisted of 183 students who were selected using cluster techniques. Data collection was carried out using a mathematics self-efficacy questionnaire and a motivation questionnaire and documentation, and the hypothesis was tested using the product moment correlation test and $t$ test. The results showed that there was a positive correlation between mathematics self-efficacy and motivation of fifth grade elementary school students, indicated by a correlation coefficient of 0.353 with a fairly strong relationship category, and there was a significant correlation between mathematics self-efficacy and motivation of fifth grade elementary school students, as seen from the $t_{\text {count }}=5.078$, greater than $t_{\text {table }}$ $=1.653$, at a significance of $5 \%$. The contribution made mathematics self-efficacy to motivation is equal to $12.5 \%$.
\end{abstract}

Keywords : elementary school; mathematics self-efficacy; students' motivation.

\section{INTRODUCTION}

Mathematics learning functions as a means of thinking and is knowledge that is compiled consistently based on deductive logic (Suryasumantri, 2007, p. 193). Therefore, students are required to have to master mathematics and develop positive attitudes so that students have extensive knowledge so that they can achieve educational goals.

Bandura (dalam Ghufron, Nur \& Rini, 2010, p. 75) argues that selfefficacy is basically the result of cognitive processes in the form of decisions, beliefs, or appreciation of the extent individuals estimate their ability to carry out certain tasks or actions needed to achieve the desired results. When students feel that they are in good condition, motivation will grow in these students to learn mathematics and be optimistic in solving mathematical problems. Meanwhile, when students feel that they are in a bad condition, students will tend to be pessimistic in solving mathematical problems.

Based on the results of an interview with one of the fifth grade 
teachers at SD Negeri 42 Pekanbaru, it was found that the fifth grade students had sufficient abilities low in solving mathematical problems, this is due to lack of student confidence in solving problems or questions given by the teacher as well as lack of motivation from students themselves. Based on the facts, it can be assumed that to increase the urge to learn mathematics arising from outside students or arising from the stimulation or help from others, so motivation and self-efficacy are needed.

Santrock in Kompri (2015, p. 232) argues about extrinsic motivation, which is doing something to get something else (a way to achieve goals) that is often influenced by external incentives such as rewards and punishments. The aspects of extrinsic motivation can be in the form of encouragement from people around students such as from parents, encouragement from friends, from teachers, from the community and from other environments (Ulandari, et al, 2014 , p. 3). extrinsic motivation can be stimulated in the form of simple praise, incentives, prizes, values and environment and a conducive climate that encourages students to learn (Hadriana, et al, 2013). In previous research consistently show that these beliefs contribute significantly to one's motivation and achievement (Yufita \& Budiarto, 2006).

Based on the description above the researcher believes that the importance of students having selfconfidence in their ability in learning mathematics (mathematics self-efficacy), because mathematics self-efficacy is thought to have a relationship with students 'extrinsic motivation or students' drive to learn because of the stimulation or help from others. Therefore, researchers are interested in examining the relationship of mathematical selfefficacy with extrinsic motivation of fifth grade elementary school students.

The formulation of the proposed problem is: 1) is there a positive relationship between mathematics selfefficacy and elementary school student motivation?, 2) is there a significant relationship between mathematics selfefficacy and elementary school student motivation?. Thus the expected goal of this study is to find a positive and significant correlation between mathematics self-efficacy and motivation of elementary school students.

\section{METHODOLOGY}

This type of research is quantitative. Quantitative research according to Sugiyono (2016, p. 14) is research that aims to collect data in the form of numbers and analysis using statistics, with the aim to test the hypotheses that have been set. The method used is the correlation method, which is a method that looks at the relationship between one or several changes with one or several other changes (Yusuf, 2017, p. 64).

The independent variable in this study is mathematics self-efficacy. The indicator of mathematics self-efficacy refers to Bandura's opinion (in Mulyani, 2016) that is, optimistic in doing 
mathematical tasks and developing mathematical abilities (dimensions of magnitude), believing in one's own ability in completing mathematical tasks and having motivation towards himself to complete mathematical tasks (strength dimension), and positive thinking in addressing mathematics learning (generality dimension). While the dependent variable in this study is extrinsic motivation. Extrinsic motivation indicators refer to Uno's opinion (2016, p. 23) namely, the existence of rewards in learning, the presence of interesting activities in learning and the existence of a conducive learning environment, in the form of applause, praise, prizes, extra value, games, competitions, group discussions, textbooks, learning media, and class atmosphere.

This research was conducted in the fifth grade elementary school cluster
I Marpoyan Damai District Pekanbaru with a total of 705 students in the $2017 / 2018$ school year. The sample selection uses a cluster technique, so the sample was selected as many as 183 students.

In this study data collection techniques using a mathematics selfefficacy questionnaire, amounting to 15 statement items, motivation questionnaire with a total of 20 statement items and documentation. The scale used is the Likert scale, with the choice of answers SS (strongly agree), S (agree), TS (disagree), and STS (strongly disagree). Data analysis techniques in this study used inferential statistics. As for testing the hypothesis, it is done by Pearson Product Moment correlation test and $t$ test.

Table 1. Mathematics Self Efficacy And Motivation Categories

\begin{tabular}{llclll}
\hline \multicolumn{3}{c}{ Mathematics Self Efficacy } & \multicolumn{3}{c}{ Motivational } \\
\hline Category & \multicolumn{1}{c}{ Boundary } & $\%$ & Category & Boundary & $\%$ \\
\hline High & $\mathrm{X} \geq 50,88$ & $18,03 \%$ & High & $\mathrm{X} \geq 27,13$ & $13,66 \%$ \\
\hline Medium & $41,54 \leq \mathrm{X}<50,88$ & $66,12 \%$ & Medium & $21,79 \leq \mathrm{X}<27,13$ & $69,40 \%$ \\
\hline Low & $\mathrm{X}<41,54$ & $15,85 \%$ & Low & $\mathrm{X}<21,79$ & $16,94 \%$ \\
\hline
\end{tabular}

The table above shows the categories of each variable, it can be seen that the mathematics self-efficacy of the fifth grade students of Elementary School I Cluster I Marpoyan Damai Pekanbaru are in the class interval 41.54 $\leq \mathrm{X}<50.88$ with a percentage $=$ $66.12 \%$, namely in the medium category. Likewise with the motivation of grade 5 elementary school students in cluster I Marpoyan Damai District Pekanbaru at class intervals of $21.79 \leq X<27.13$ with a percentage $=69.40 \%$, namely in the medium category. 
Table 2. Results Of Mathematics Self-Efficacy Correlation Test With Motivation

\begin{tabular}{ccccc}
\hline Correlasion & $\begin{array}{c}\text { Correlatin } \\
\text { coefficient }\left(r_{\text {count }}\right. \\
\text { it })\end{array}$ & $r_{\text {tabel }}$ & $\begin{array}{c}\text { Interpretation of } \\
\text { Correlation } \\
\text { Coefficients }\end{array}$ & Information \\
\hline $\begin{array}{c}\text { Self-efficacy } \\
\text { mathematically } \\
\text { with motivation }\end{array}$ & 0,353 & 0,144 & Strong enough & $\begin{array}{c}\text { There is a } \\
\text { positive } \\
\text { relationship }\end{array}$ \\
\hline
\end{tabular}

In the table above it can be seen that the correlation coefficient obtained is equal to 0.353 with the interpretation of the correlation coefficient strong enough. Because the value of $r_{\text {count }}$ (0.353)> $r_{\text {tabel }}(0.144)$ then $\mathrm{Ho}$ is rejected, meaning that there is a positive relationship between mathematics self-efficacy and the motivation of fifth grade elementary school students in cluster I Marpoyan Damai Pekanbaru. The contribution of mathematics self-efficacy to motivation is $12.5 \%$.

Table 3. Results of tests of mathematics self-efficacy significance with motivation.

\begin{tabular}{cccc}
\hline Correlasion & $\mathrm{T}_{\text {count it }}$ & $\mathrm{t}_{\text {tabel }}$ & Information \\
\hline $\begin{array}{c}\text { Mathematics self-efficacy } \\
\text { with motivation }\end{array}$ & 5,078 & 1,653 & $\begin{array}{c}\text { There is a significant } \\
\text { relationship. }\end{array}$ \\
\hline
\end{tabular}

Based on the results of the significance test in the table above, the value of $t_{\text {count }}(5,078)>t_{\text {table }}(1,653)$ is obtained. It can be seen that the $t-$ count is greater than the table then Ho is rejected, meaning that there is a significant correlation between mathematics self-efficacy and the motivation of fifth grade elementary school students in cluster I Marpoyan Damai Pekanbaru

To see the correlation between mathematics self-efficacy and student motivation is tested using the correlation test (Pearson Product Moment) with $\mathrm{a}=0.05$. Meanwhile, to see the significance is done by t test. The results of data analysis show that between mathematics self-efficacy and motivation have a positive and significant direction of the relationship.
This means that the mathematics selfefficacy variable can be used as a predictor to predict student motivation. The higher the mathematics selfefficacy, the higher the motivation. Conversely, the lower the mathematical self-efficacy, the lower the motivation. So that with the confidence in students of their ability in learning mathematics it will foster extrinsic motivation in students to achieve the goals of learning mathematics in the process of learning activities in school..

In accordance with the opinion of Pervin \& John (in Bandura, 1997) which suggests that someone who has high self-efficacy will be more motivated to achieve goals. The higher the level of one's self efficacy, the level the motivation will be higher too. This is reflected by the amount of effort done 
and his perseverance in overcoming the existing obstacles. He will continue to do his tasks and not easily give up and survive when faced with difficulties. People who have high self-efficacy will try harder in overcoming the obstacles that exist.

In line with Purningsih, et al (2016, p. 3) students who have higher self-efficacy will be confident in their ability to overcome difficulties, there needs to be challenges to improve it. In the end, in this challenge students will bring up motivation in learning especially in learning mathematics.

This is also in line with Santrock (2008) which states that the factors that influence learning motivation consist of internal and external factors. One of them is confidence in his abilities.

The results of the categories of mathematis self-efficacy and student motivation indicate that the two variables are in the moderate category. This is in line with the statement put forward by Santrock (2011, p. 450) that self-efficacy is also the next factor that has a relationship with learning motivation. Self-efficacy is the belief in a person to complete the tasks given to him. According to Santrock, self-efficacy is the belief that "I can". Students with high self-efficacy will issue a statement, "I know that I am able to master this material", and "I will do my best when this activity takes place".

The results of the categories of mathematical self-efficacy and student motivation indicate that the two variables are in the moderate category. This is in line with the statement put forward by Santrock (2011) that selfefficacy is also the next factor that has a relationship with learning motivation.
Self-efficacy is the belief in a person to complete the tasks given to him. According to Santrock, self-efficacy is the belief that "I can". Students with high self-efficacy will issue a statement, "I know that I am able to master this material", and "I will do my best when this activity takes place". having high self-efficacy will be able to complete challenging tasks. Self-efficacy will affect student achievement. If students believe that an assignment can be completed, the motivation to complete the task will strengthen.

\section{CONCLUSION}

There is a positive relationship between mathematics self-efficacy and motivation of elementary school students, then $\mathrm{Ho}$ is rejected. This is indicated by the results of the correlation coefficient of 0.353 with a fairly strong relationship category. And the contribution is $12.5 \%$. That is, the higher the mathematical self-efficacy, the higher the motivation, conversely the lower the mathematics self-efficacy, the lower the motivation of students.

There is a significant relationship between mathematical self-efficacy and motivation of elementary school students, this is indicated by the acquisition of $t_{\text {count }}(5,078)>t_{\text {table }}$ $(1,653)$, it can be concluded Ho hypothesis is rejected where there is a significant relationship between motivation and mathematical selfefficacy of elementary school students. 


\section{REFERENCES}

Bandura, A. (1997). Self-efficacy Toward $A$ Unifying Theory of Behavioral Psychology. Review.

Hadriana, et al. (2013). The Relationship between Motivations and Self-Learning and the English Language Achievement in Secondary High School Students. Asian Social Science. 9(12): 38. (Online). www.ccsenet.org/ass (diakses 1 November 2018).

Ghufron, Nur, M \& Rini, R. (2010). Teori-teori Psikologi. Yogyakarta: Arruzz Media.

Suryasumant, J. S. (2007). Filsafat IImu Sebuah Pengantar Populer. Jakarta: Pustaka Sinar Harapan.

Kompri. (2015). Motivasi Pembelajaran Perspektif Guru dan Siswa. Bandung: Remaja Rosdakarya.

Purningsih, A, et al. (2016). Hubungan Self Efficacy dengan Motivasi Belajar Matematika Siswa Kelas V SD Se-Gugus 6 Kecamatan Tampan Kota Pekanbaru. Jurnal Online Mahasiswa FKIP. 3(2). 3. (Online). https://jom.unri.ac.id/index.php/JO MFKIP/article/view/12015/11660 (diakses 1 November 2019).

Santrock, J. W. (2008). Educational Psychology.Third Edition. New York: McGraw - Hill Companies.

Santrock, J. W. (2011). Educational Psychology: Fifth Edition. New York: McGraw - ill Companies.

Sugiyono. (2016). Metode Penelitian Pendidikan Pendekatan Kuantitatif, Kualitatif, dan R\&D. Bandung: Alfabeta.

Ulandari, K. et al. (2014). Hubungan Antara Motivasi Belajar dengan Prestasi Belajar Siswa SD Kelas V
Semester Ganjil di Desa Buruan. Jurnal Mimbar. 2 (1): 3. (Online). https://ejournal.undiksha.ac.id/ind ex.php/JJPGSD/article/view/2312 (diakses 1 November 2019).

Uno, H.B. (2011). Teori Motivasi dan Pengukurannya. Jakarta: Bumi Aksara.

Yufita \& Budiarto. (2006). Motivasi Kerja Guru Ditinjau Dari Self-Efficacy dan Iklim Sekolah. Jurnal IImiah Psikologi Industri dan Organisasi. 8(2): 181-195. (Online). http://garuda.ristekdikti.go.id/jour nal/article/62905 (diakses 1 November 2019).

Yusuf, A. M. (2017). Metode Penelitian Kuantitatif, Kualitati \& Penelitian Gabungan. Bandung: Alfabeta. 
Journal of Teaching and Learning in Elementary Education (JTLEE) Vol. 3 No. 1, February 2020

(C)All rights reserved

Printed in Indonesia
ISSN (Print) : :2615-4528

ISSN (Online) : 2622-3023

DOI: http://dx.doi.org/10.33578/jtlee.v3i1.7831 